\title{
EXOCRINE GLANDS OF Schwarziana quadripunctata (HYMENOPTERA, APINAE, MELIPONINI)
}

\author{
CRUZ-LANDIM, C. and REGINATO, R. D. \\ Instituto de Biociências de Rio Claro, Departamento de Biologia, Av. 24A, 1515, C.P. 199, \\ CEP 13506-900, Rio Claro, SP, Brazil \\ Correspondence to: Carminda Cruz-Landim, Instituto de Biociências de Rio Claro, Departamento de \\ Biologia, Av. 24A, 1515, C.P. 199, CEP 13506-900, Rio Claro, SP, Brazil, e-mail: depbio@rc.unesp.br \\ Received January 12, 2000 - Accepted May 29, 2000 - Distributed August 31, 2001
}

(With 5 figures)

\begin{abstract}
This article describes the location, anatomy, histology and ontogeny of adult Schwarziana quadripunctata exocrine glands. These glands appear either as individualized organs (salivary gland system and Dufour gland) or as epidermis differentiation (tegumentary glands). Variations in the occurrence and degree of development among colony components with regard to their degree of maturity are also described.
\end{abstract}

Key words: exocrine glands, males, female castes, development.

\section{RESUMO}

\section{Glândulas exócrinas de Schwarziana quadripunctata (Hymenoptera, Apinae, Meliponini)}

O presente artigo descreve a localização, a anatomia, a histologia e o desenvolvimento das glândulas exócrinas presentes em operárias, rainhas e machos de Schwarziana quadripunctata. As glândulas apresentam-se como órgãos individualizados (glândulas do sistema salivar e glândula de Dufour) ou como simples diferenciações da epiderme (glândulas tegumentares). As variações na ocorrência e no grau de desenvolvimento dos componentes da colônia, ou de seu grau de amadurecimento, também são apresentadas.

Palavras-chave: glândulas exócrinas, machos, castas femininas, desenvolvimento.

\section{INTRODUCTION}

Bordas (1895) pioneered the comparative study of the occurrence, distribution and morphology of the exocrine glands of the main families of Apocrita and Aculeata Hymenoptera.

Other workers later studied bee glands through a comparative morphological and distributive approach (Cruz-Landim, 1967, 1992, 1994, 1996; Costa-Leonardo \& Cruz-Landim, 1977). In certain species, the differences between sexes and castes regarding glandular presence or development were studied (Costa-Leonardo, 1978; CruzLandim et al., 1980a, b) and in others, even details on cell ultrastructure and secretion cycles are known (Cruz-Landim \& Hadek, 1969; Cruz-Landim et al., 1998).
These studies found that bees have a high number of exocrine glands distributed throughout their bodies (Velthuis et al., 1997). These glands basically consist of Class I or III glandular cells, according the Noirot \& Quennedey $(1974,1991)$ classification, which may organize as individualized organs or remain part of the tegument locally constituted by modified epidermal cells (Cruz-Landim, 1996).

Glands organized as individualized organs are both those linked to the labial appendices, known as salivary system glands (the labial glands, the mandibular glands and the hypopharyngeal glands), and to the sting apparatus (venom and Dufour glands) (Cruz-Landim, 1996). Tegumentar glands have a wider distribution (Cruz-Landim $e t$ al., 1998). 
They may be found in the head, abdomen and legs (Cruz-Landim et al., 1998) and were recently described in the mesothorax (Vison, 1994; Minckley, 1994; Cruz-Landim \& Reginato, 1999) as well.

This paper discusses Schwarziana quadripunctata exocrine glands, focusing on the comparative aspects of their occurrence, development and secretion histochemical nature in workers, queens and males.

\section{MATERIAL AND METHODS}

The material used in this study consisted of male, worker and queen specimens of the stingless bee Schwarziana quadripunctata. We were kindly provided with the majority of the studied specimens by Dr. Vera Lucia Imperatriz Fonseca, from the Bee Laboratory of the São Paulo Ecology Department (IB-USP), SP, Brazil, where the voucher specimens are deposited.

Newly emerged nurse and forager workers, mature males and virgin and fisogastric queens were used.

The glands were studied through light microscopy and scanning electron microscopy and measured in order to assess their stage of development.

For light microscopy (LM), the dissected glands were fixed in 4\% Paraformaldehyde and after dehydration by Ethanol, embedded in JB4 historesin. Sections of $6 \mu \mathrm{m}$, placed on histological slides, were stained with Hematoxylin and Eosin, for a general examination of histological features, and with $1 \%$ toluidine blue $\mathrm{pH} 4.0$, for cytoplasmic basophylly determination, bromophenol blue $\mathrm{pH}$ 5 for proteins and alcian blue for neutral polysaccharides. The histochemical reactions followed the Pearse (1960) appendix protocols.

For scanning electron microscopy (SEM), the glands were fixed with Karnovisky, dehydrated with Ethanol and Acetone, dried to the critical point and covered with Gold, before examination through a Jeol JSM-P15, tabletop scanning electron microscope P15.

The gland stage of development was evaluated by measuring 20 sections of each gland from 8 different workers at each functional age (newly emerged, nurse and forager), 8 virgin queens and 8 males. This evaluation was restricted to the salivary gland system. The fisogastric queen was not studied, due to the difficulty in obtaining a suffi- ciently large number of specimens. The average and standard deviations were calculated for each sample and the Tukey test at a 5\% significance level was applied to differentiate them.

\section{RESULTS AND DISCUSSION}

Bees have a high number of exocrine glands distributed throughout their bodies, entirely of ectoderm origin. Some of these glands form individualized organs, while others are merely differentiated epidermal cells, constituting the tegumentar or dermal glands.

Table 1 shows the occurrence and degree of development of these glands in S. quadripunctata queens, workers and males. The stage of development was established through the histological aspect of the secretory units and, in the case of some glands, by measurement (Table 2).

As may be seen, with the exception of the hypopharyngeal glands, only head glands present differences with regard to the degree of development. The morphology of head glands that constitute individualized organs (salivary, mandibular and hypopharyngeal glands) is currently well known (Cruz-Landim, 1967; Costa-Leonardo \& Cruz-Landim, 1977; Salles \& Cruz-Landim, 1998) and $S$. quadripunctata do not present fundamental differences regarding prior described conditions (Fig. 2) of other Meliponini species.

Head salivary glands consist of alveolar secretory units (Fig. 1A, B), lined by a thin secretory epithelium, that provides a wide inner lumen in which a oil-like secretion is stored.

The thoracic salivary gland is made up of tubular secretory units (Fig. 1C, D) and the secretory epithelium consists of conic cells. The lumen of the tubules is narrow and lined by a cuticle (Fig. 1D).

Watery secretion is first accumulated in a subcuticular space before crossing the cuticle to be delivered.

The mandibular gland (Fig. 1E, F) is constituted by a mass of Class III secretory cells connected to a membranous sac, which functions as a secretion reservoir.

The hypopharyngeal gland displays the normal constitution, viz., spherical secretory elements, also consisting of Class III secretory cells, linked to an axial excretory duct (Fig. 1G, H). 
Special attention was paid to tegumentar glands present in the head, represented by the glossal (Fig. 2A, B, C) glands and the intramandibular glands (Fig. 2D, E, F). There are secretory structures in both locations, consisting of Class I and III glandular cells (Fig. 3A, B, C).

Inside the mandible, Class I cells form an epithelium on the inner wall of the mandible, while Class III cells are located close to the outer wall, tending to group at the base of the mandible (Figs. $2 \mathrm{~F}$ and $3 \mathrm{~B}$ ). These cell canals openings may be noted near the mandible-to-head articulation and along the dorsal side of the mandible (Fig. 2D, E). These gland stages of development apparently does not vary neither between different colony individuals (queens, workers and males) nor at different ages or functional phase of these individuals (Table 1).

Glossal glands are sited on the inner surface of the wall that limits the glossa lodge, and are found in queens, workers and males apparently without variation during their lifetimes (Table 1).

Nevertheless, salivary system glandular organs present some differences as to the size of secretory units, interpreted as indicating different functional stages (Tables 1 and 2, Fig. 1).

As may be noted, mandibular glands do not change size during a worker's lifetime, are larger in queens and present an identical development in workers and males.

The head labial gland has a larger size in workers, in all other individuals presenting identical sizes.

The thorax salivary gland, however, is smaller in newly emerged workers, forager workers, queens and males, while larger in nurse workers. The hypopharyngeal gland is only larger in nurse workers.

The results of the histochemical reactions also indicated differences between glands from different individuals (Table 3 ).

TABLE 1

Occurrence and developmental state of exocrine glands in Schwarziana quadripunctata workers, queens and males.

\begin{tabular}{|c|c|c|c|c|c|c|c|}
\hline \multirow[b]{2}{*}{ Gland } & \multirow[b]{2}{*}{ Location } & \multicolumn{3}{|c|}{ Workers } & \multicolumn{2}{|c|}{ Queens } & \multirow[b]{2}{*}{ Males } \\
\hline & & $\begin{array}{c}\text { Newly } \\
\text { emerged }\end{array}$ & Nurse & Foragers & Virgin & Fisogastric & \\
\hline Head salivary & Head & ++ & +++ & ++ & ++ & ++ & ++ \\
\hline Thorax salivary & Thorax & +++ & ++++ & ++ & +++ & +++ & ++ \\
\hline Mandibular & Head & ++ & +++ & ++ & ++ & +++ & ++ \\
\hline Intra-mandibular & Head & ++ & ++ & ++ & ++ & ++ & +++ \\
\hline Glossal & Head & ++ & ++ & ++ & ++ & ++ & ++ \\
\hline Hypopharyngeal & Head & ++ & +++ & ++ & 0 & 0 & ++ \\
\hline Mesothoracic & Thorax & ++ & ++ & ++ & +++ & +++ & + \\
\hline Coxal & Coxa & + & + & + & + & + & - \\
\hline Trocanter & Trocanter & - & - & - & + & + & - \\
\hline Femural & Femur & + & + & + & $+\mathrm{s}$ & $+\mathrm{s}$ & - \\
\hline Tibial & Tibia & + & + & + & + & + & - \\
\hline Basitarsal & Basitarsus & + & + & + & - & - & - \\
\hline Tarsal & Last tarsomere & $+\mathrm{s}$ & $+\mathrm{s}$ & $+\mathrm{s}$ & $+\mathrm{s}$ & $+\mathrm{s}$ & $+\mathrm{s}$ \\
\hline Wax & $\begin{array}{l}\mathrm{III}, \quad \mathrm{IV}, \quad \mathrm{V}, \\
\text { Abdominal tergites }\end{array}$ & ++ & +++ & + & 0 & 0 & 0 \\
\hline Class III glands & Abdominal* ${ }^{*}$ tergites & + & + & + & +++ & +++ & 0 \\
\hline Class I glands & Abdominal $* *$ tergites & - & - & - & +++ & ++++ & 0 \\
\hline Dufour & Sting apparatus $* * *$ & + & + & + & ++ & +++ & 0 \\
\hline
\end{tabular}


TABLE 2

Average, standard deviation and statistical differences betwenn section areas os schwarziana quadripunctata salivary system glands.

\begin{tabular}{|l|c|c|c|c|}
\hline & Mandibular gland & Head salivary gland & Thorax salivary gland & Hypopharyngeal gland \\
\cline { 2 - 5 } & Average & Average & Average & Average \\
\hline Newly emerged worker & $32884 \mathrm{~b} \pm 17004$ & $20910 \mathrm{~b} \pm 9752$ & $82217 \mathrm{bc} \pm 34045$ & $23026 \mathrm{~b} \pm 7050$ \\
\hline Nurse worker & $34094 \mathrm{~b} \pm 15229$ & $111160 \mathrm{a} \pm 65439$ & $201936 \mathrm{a} \pm 109405$ & $40262 \mathrm{a} \pm 15995$ \\
\hline Forager worker & $32546 \mathrm{~b} \pm 12387$ & $24861 \mathrm{~b} \pm 23966$ & $36257 \mathrm{c} \pm 29073$ & $16705 \mathrm{bc} \pm 10396$ \\
\hline Virgin queen & $61125 \mathrm{a} \pm 26361$ & $37736 \mathrm{~b} \pm 11489$ & $126175 \mathrm{~b} \pm 50609$ & \\
\hline Male & $32985 \mathrm{~b} \pm 12842$ & $26561 \mathrm{~b} \pm 9046$ & $45565 \mathrm{c} \pm 20475$ & $14210 \mathrm{c} \pm 4994$ \\
\hline
\end{tabular}

Different letters indicate statistical differences at a $5 \%$ level (Tukey test) $\propto=0,05$.

Toluidine blue showed that cytoplasm basophilly is higher in newly emerged and nurse workers' hypopharyngeal glands, as well as the protein content in the nursing phase. The mandibular gland mainly produces lipid substances and, accordingly, showed weak basophilly and a weak reaction to bromophenol blue in all functional phases. Alcian blue indicated the presence of moderate amounts of basic polysaccharides in this gland during the nursing phase.

The same results were obtained for the head salivary gland, also producing lipid substances. The thoracic branch of the salivary gland, however, was highly positive in newly emerged workers and average in nurses and foragers. The amount of protein, assessed by the intensity of bromophenol blue staining, was the same during all phases of workers' lifetimes and alcian blue only indicated a decrease in foragers.

These results agree with the presumed function of these glands. The head glands probably produce substances that serve to lubricate the bucal parts or to maintain the cuticular surface hydrocarbons and, therefore, do not change with the type of individual or phase of life. Glands structured as individualized organs have a secretory cycle linked to the phase of life. The hypopharyngeal gland in Apis mellifera produces brood food and it is presumed that the same occurs in meliponines. This food consists mainly of protein, so high basophilly and high content of proteins is expected in this gland during the nursing phase, as well as its decline in forager workers.

The mandibular gland in Apis mellifera workers is thought to produce a part of the brood food and, in queens, pheromones that assure the queen's reproductive dominance (Free, 1961). These substances have an oil-like aspect, which agrees with the unfeasibility of demonstrating basophilly and the presence of protein in worker glands of all phases. The larger size of these glands in queens may indicate, as in A. mellifera, that some pheromone compounds are produced in them.

Concerning salivary glands, the thoracic branch is noted by Simpson (1963) and Simpson \& Riedel (1964) as producing digestive enzymes, mainly invertase, while the head branch produces oil-like secretion. Simpson (1963) suggests that oil produced by the head salivary gland may be used for wax modeling or labial appendices lubrication and the secretion of the thoracic branch for moistening food before ingestion. The histochemical results provided in Table 3 agree with these possible functions of the salivary glands.

The enzyme content in the thoracic gland is believed to be low, justifying the merely average positiveness to bromophenol blue in nurse glandular cells. In the thorax, S. quadripunctata have Class III tegumentary glands at the side of the mesothorax, as has already been described (Cruz-Landim \& Reginato, 1999), and tegumentar glands in the leg segments. The tegumentary glands present in legs also consist of Class I cells (basitarsus) or Class III cells (coxa, trocanter, femur and tibia); in the last tarsomere of all types of individuals; however, a bag formed by an epidermal evagination, the tarsal gland, is found. A saculiform gland was also observed in the queen's femur (Table 3). In the abdomen, $S$. quadripunctata have tegumentar, dorsal glands constituted by Class I and Class III glandular cells (Fig. 4A, B, C), and a Dufour gland (Fig. 5) linked to the atrophied sting apparatus (Camargo, 1974). 

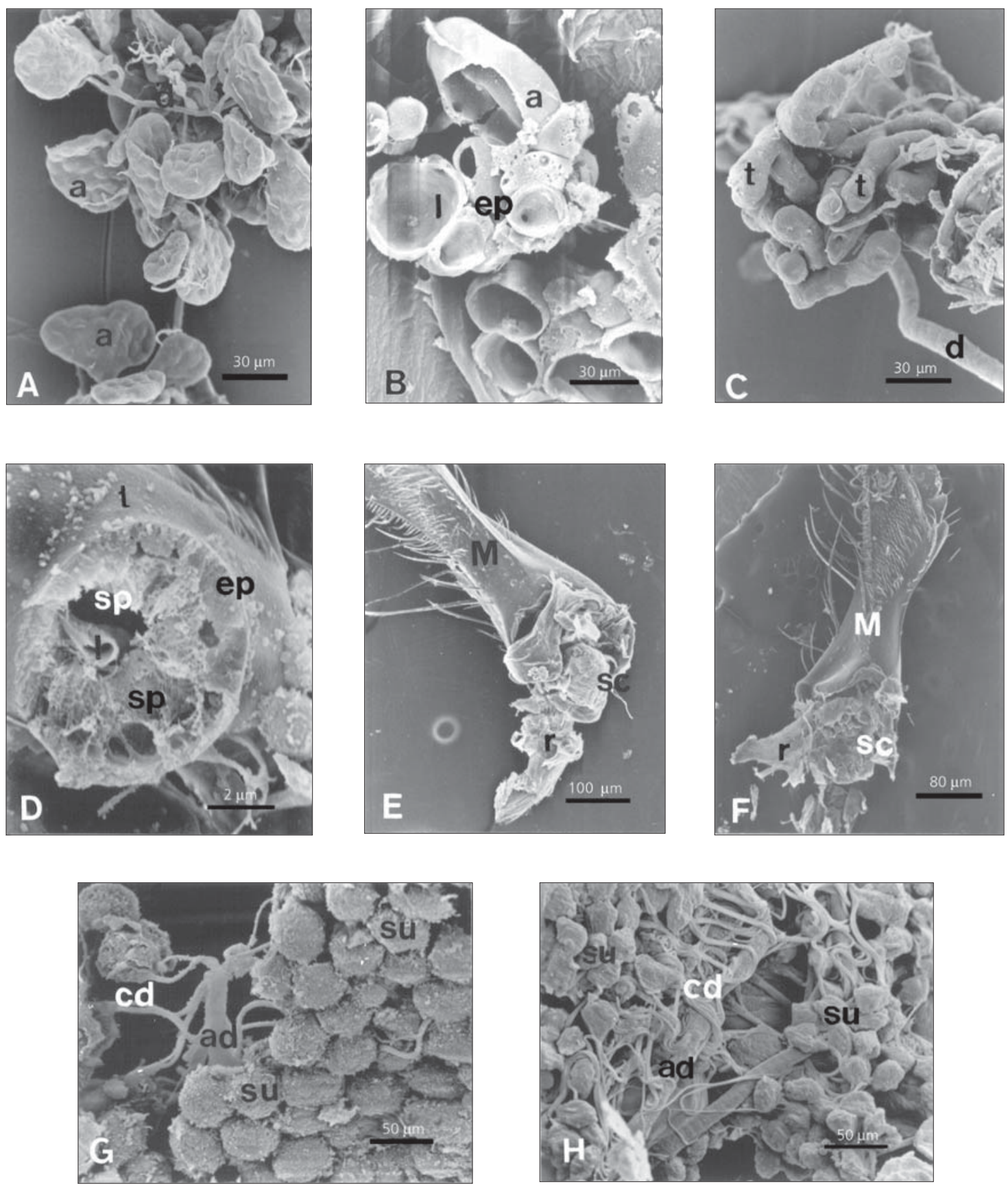

Fig. 1 - SEM micrograph of glands from the salivary system of $S$. quadripunctata. A and B. Head salivary glands alveoli (a) seen from the outside (A) and from the inside (B). Note the flat epithelial cells (ep) and the wide lumen (1). C and D. Thoracic salivary glands tubules (t) seen from the outside (C) and in cross-section (D). Note the cuticle that lines the lumen (1) and the secretory space (sp) between it and the secretory cells (ep). E and F. Mandibular glands from workers (E) and males (F) showing the secretory cells (sc) and the reservoir (r). G and H. Worker (G) and male (H) hypopharyngeal glands showing the males' smaller secretory units.

$\mathrm{M}=$ mandible; $\mathrm{ad}=$ axial excretory canal; $\mathrm{su}=$ secretory unit; $\mathrm{cd}$ = collector canal. 
The Dufour gland was observed in the queen only and takes the form of an elliptical sac.

Tegumentary abdominal glands in workers (Table 1) are represented by Class I wax glands located in III, IV, V and VI tergites and Class III glands located in II and VIII tergites.

In queens, class I glandular cells are present in the III tergite and their function is unknown. Class III glandular cells in queens are present in III, IV, V and VIII tergites.
Class III glandular cells of VIII tergite correspond to the A. mellifera Koschewnikow gland. The openings of these glands may be seen among the hairs of the laterals of the tergites (Fig. 4C).

Concluding, it may be stated that Schwarziana quadripunctata has an exocrine glandular system very similar to other meliponines, but some glands not reported or rarely reported in bees were described in this paper, such as the intramandibular, glossal and leg glands.
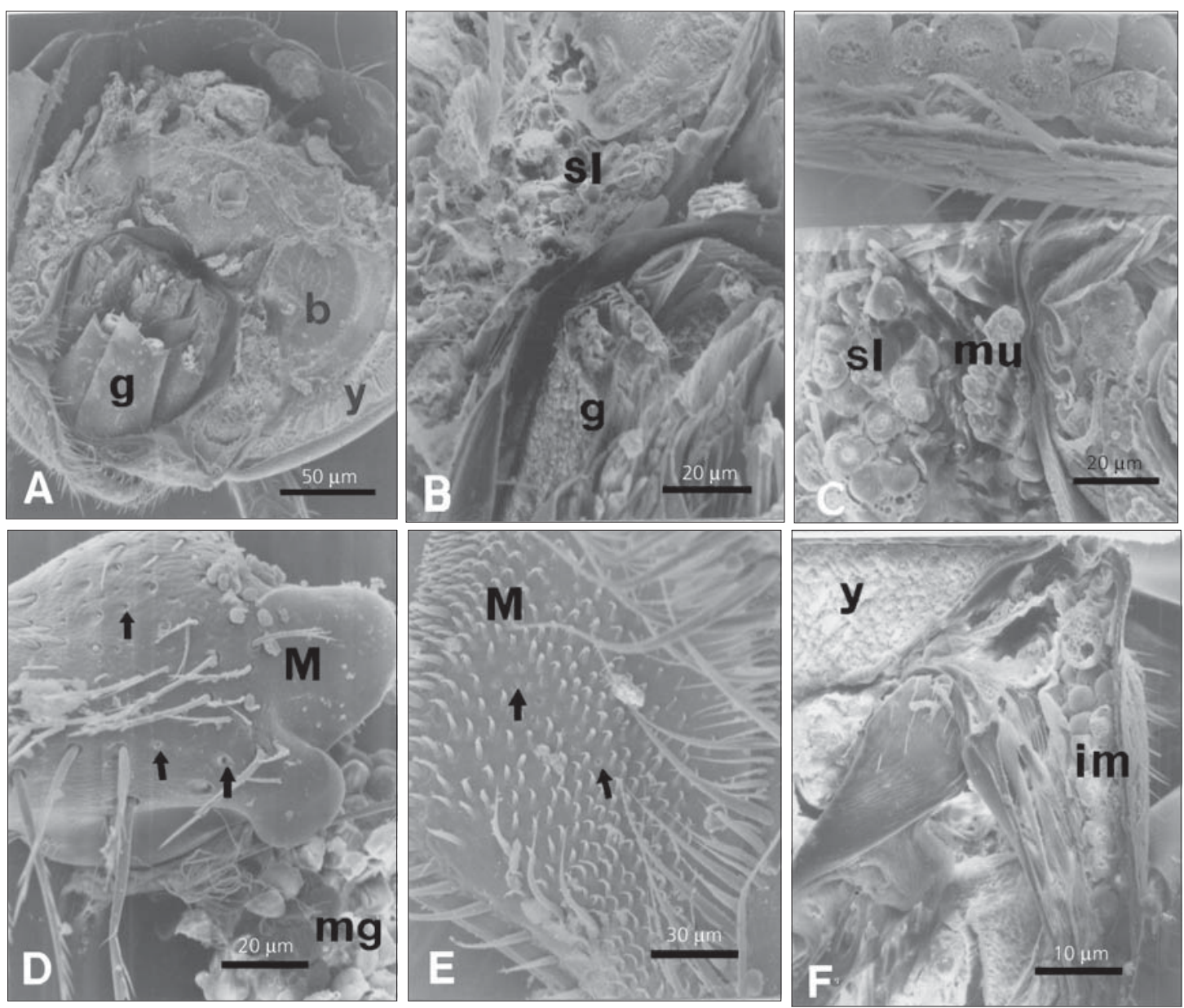

Fig. 2 - SEM micrograph of head tegumentary glands of S. quadripunctata. A, B and C. Glossal glands (sg). (A) Frontal section of the head showing the lodge of the glossa $(\mathrm{g})$, in which the glands are located, in its laterals. B and C. Magnifications of the glossa region showing the secretory cells (sl) from a worker (B) and from a male (C). D, E and F. Intramandibular gland (im). D and E. Openings (arrows) of the Class III glandular cells in the mandible (M) basis (D) and along the dorsal side (E). F. Mandible section showing the intramandibular (im) Class III glandular cells. $\mathrm{b}=$ brain $; \mathrm{cy}=$ compound eye $\mathrm{mg}=$ mandibular gland . 

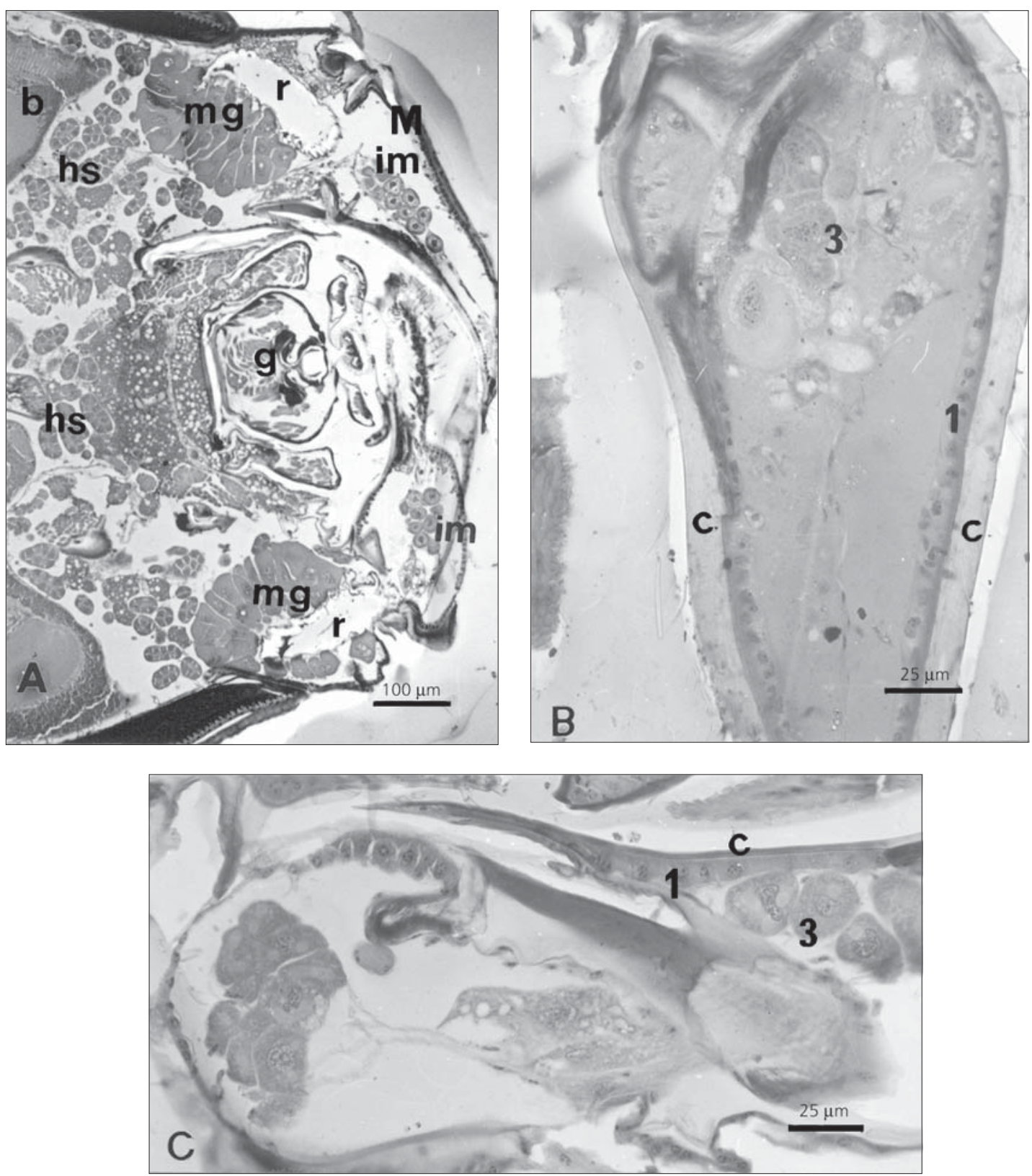

Fig. 3 - Histological aspects of the head glands of S. quadripunctata. A. Frontal section of the head showing the mandibular gland $(\mathrm{mg})$, the intramandibular gland (im) and the head salivary gland (hs). B. Longitudinal section of the mandible showing the Class I secretory cell (1) and Class III (3) secretory cells. C. Sublingual Class I (1) and Class III (3) gland cells.

$\mathrm{M}=$ mandible $; \mathrm{g}=$ glossa $; \mathrm{r}=$ mandibular gland reservoir; $\mathrm{b}=$ brain; $\mathrm{c}=$ tegument cuticle . 

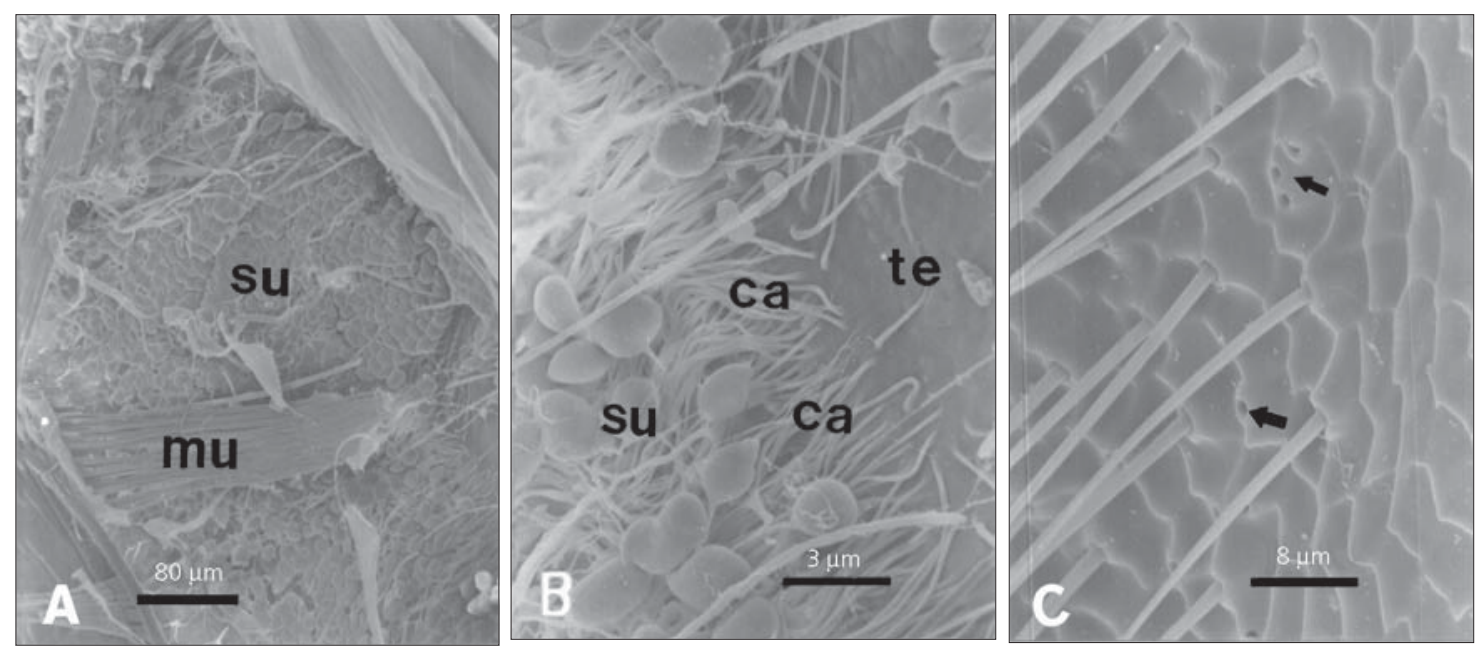

Fig. 4 - SEM micrograph of abdomen tegumentary glands of $S$. quadripunctata. A and B. Inner view of the queen $4^{\text {th }}$ tergite, showing in B the gland cell (su) and in C the canal (ca) reaching the tegument (te). C. Outer view of the openings of Class III gland cells (arrows). mu = segmental muscles.

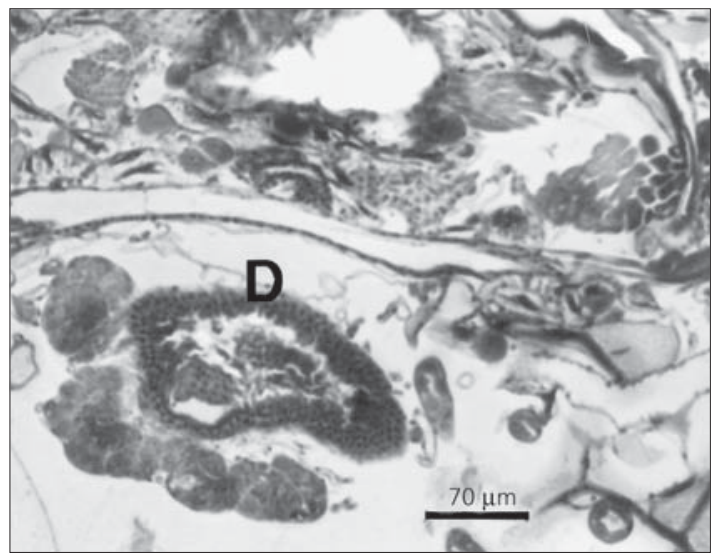

Fig. 5 - Histological view of the Dufour gland (D) of a S.quadripunctata virgin queen.

TABLE 3

Results of histochemical reactions applied to glands of the salivary system of Schwarziana quadripunctata workers.

\begin{tabular}{|l|c|c|c|c|c|c|c|c|c|c|c|c|}
\hline & \multicolumn{3}{|c|}{ Hypopharyngeal gland } & \multicolumn{3}{c|}{ Mandibular gland } & \multicolumn{3}{c|}{ Head salivary gland } & \multicolumn{3}{c|}{ Thorax salivary gland } \\
\cline { 2 - 22 } & N. emerged & Nurse & Forager & N. emerged & Nurse & Forager & N. emerged & Nurse & Forager & N. emerged & Nurse & Forager \\
\hline Toludine blue & +++ & +++ & ++ & + & + & + & + & + & + & ++ & ++ & ++ \\
\hline Bromophenol blue & + & +++ & + & - & + & + & + & + & + & ++ & ++ & ++ \\
\hline Alcian blue & - & ++ & - & - & ++ & - & - & ++ & + & ++ & ++ & + \\
\hline
\end{tabular}


Acknowledgments - The authors are grateful to Dr. V. L. Imperatriz-Fonseca for providing the specimens used in this study.

\section{REFERENCES}

BORDAS, M. L., 1895, Appareil glandulaire des Hyménoptères. Ann. Sci. Nat. Zool., 19: 1-362.

CAMARGO, J. M. F., 1974, Notas sobre a morfologia e biologia de Plebeia (Schwarziana) quadripunctata (Hymenoptera, Apidae). Studia entomologia, 17: 433470 .

COSTA-LEONARDO, A. M., 1978, Glândulas intramandibulares em abelhas sociais. Ciência e Cultura, 30: 835-838.

COSTA-LEONARDO, A. M. \& CRUZ-LANDIM, C., 1977, Estudo comparativo das glândulas do sistema salivar dos Apidae Sociais (Hymenoptera). Rev. Brasil. Biol., 37: 649-663.

CRUZ-LANDIM, C., 1967, Estudo comparativo de algumas glândulas das abelhas (Hymenoptera, Apoidea) e respectivas implicações evolutivas. Arq. Zool., São Paulo, 15: 117-290.

CRUZ-LANDIM, C., 1992, Glândulas exócrinas presentes nos adultos das abelhas sociais. Naturalia, Supl., pp. 79-80.

CRUZ-LANDIM, C., 1994, Polimorfismo na ocorrência de glândulas exócrinas nas abelhas (Hymenoptera, Apoidea). Anais do Primeiro Encontro sobre Abelhas de Ribeirão Preto. pp. 118-129.

CRUZ-LANDIM, C., 1996, Glândulas tegumentares abdominais de abelhas. Ocorrência e ultra-estrutura. Anais do Encontro sobre Abelhas, 2, Ribeirão Preto, SP, pp. 67-75.

CRUZ-LANDIM, C. \& HADEK, R., 1969, Ultrastructure of Apis mellifera hypopharyngeal gland. Proc. VI Congr. IUSSI, Bern, pp. 121-130.

CRUZ-LANDIM, C., HÖFLING, M. C. \& IMPERATRIZFONSECA, V. L., 1980a, Tergal and mandibular gland in queens on Paratrigona subnuda (Moure) (Hymenoptera, Apidae). Morphology and associated behaviour. Naturalia, 5: 121-133.

CRUZ-LANDIM, C., SANTOS, S. M. F. HÖFLING, M. C., 1980b, Sex determination in Bees. XV. Identification of Queens of Melipona quadrifasciata anthidioides (Apidae). With the worker phenotype by a study of the tergal glands. Rev. Brasil. Genet., 3: 295-302.
CRUZ-LANDIM, C., SILVA DE MORAES, R. L. M., SALLES, H. C. \& REGINATO, R. D., 1998, Note on glands present in Meliponinae (Hymenoptera, Apidae) Bee Legs. Revta. Brasil. Zool., 15: 159-165.

CRUZ-LANDIM, C. \& REGINATO, R. D., 1999, Preliminar Report on the Presence of Tegumentar glands in the Thorax of Meliponinae Bees (Hymenoptera, Apidae). Rev. Brasil., Biol., 59: 167-172.

FREE, J. B., 1961, Hypopharyngeal gland development and division of labor in honey bee (Apis mellifera L.) colonies. Proc. R. Entomol. Soc. Lond. Ser. A. Gen. Entomol., 36: 5-8.

MINCKLEY, R. L., 1994, Comparative morphology of the mesosomal gland in male large carpenter bees, Apidae: Xilocopini. Biol. J. Linnean Soc., 53: 291308.

NOIROT, C. \& QUENNEDEY, A., 1974, Fine structure of insect epidermal glands. Ann. Rev. Entomol., 19: 61-80.

NOIROT, C. \& QUENNEDEY, A., 1991, Glands, gland cells, glandular units some comments on terminology and classification. Annls. Soc. Ent. Fr., 27: 123-128.

PEARSE, A. G. E., 1960, Histochemistry Theoretical and Applied. J \& A Churchill Ltd., London, p. 998.

SALLES, H. C. \& CRUZ-LANDIM, C., 1998, Levantamento das glândulas exócrinas presentes em Camargoia nordestina Moure, 1989 (Hymenoptera, Apidae, Meliponinae). Revta. Brasil. Ent., 41: 297-302.

SIMPSON, J., 1963, The source of that saliva that honeybees use to moisten materials they drew with their mandibles. J. Apicult. Res., 2: 115-116.

SIMPSON, J. \& RIEDEL, J. B. M., 1964, Discharge and manipulation of labial gland secretion by workers of Apis mellifera L. (Hymenoptera, Apidae). Proc. $R$. Ent. Soc. Lond., 39: 76-82.

VELTHUiS, H. H. W., BIESMEYER, J. C., CAMARGO, J. M. F., COLB, L., CORTOPASSI-LAURINO, M., CRUZ-LANDIM, C., ENGELS, W., IMPERATRIZFONSECA, V. L., KOEDAM, D., VALE, M. P., RAMALHO, M., SILVA MATOS, E. V. \& ZUCCHI, R., 1997, Biologia de Abelhas sem Ferrão. Departamento de Etologia, Universidade de Utrecht, Holanda, 33p.

VINSON, S. B., 1994, Ultrastructure of the mesosomal gland of Xylocopa micans Lepeletier (Hymenoptera: Anthophoridae) associated with pheromone release. Int. J. Insect Morphol. \& Embriol., 23: 243-252. 